\title{
Quercetin Extracted from Broccoli Attenuates the Renewal of Hepatic Cells via Downregulation of TGF $\beta-1$ and Arresting of HSCs Activation in Mice
}

\author{
Nabila Zein 1,*(D), Fathy Yassin 2(D), Marwa Othman 1(D) \\ 1 Chemistry Department, Biochemistry Division, Faculty of Science, Zagazig University, Egypt; dr.nabila.zein@gmail.com \\ (N.Z.); marwabiochemist@gmail.com (M.O.); \\ 2 Chemistry Department, Organic Chemistry Division Faculty of Science, Zagazig University, Egypt; \\ Fathy_yassin@yahoo.com (F.Y.); \\ * Correspondence: dr.nabila.zein@gmail.com;
}

Received: 8.12.2020; Revised: 31.12.2020; Accepted: 2.01.2021; Published: 4.01.2021

\begin{abstract}
Fibrosis of hepatic cells is a consequence of various etiologies of serious liver injury. Antifibrotic properties of quercetin extracted from broccoli were detected in mice with liver fibrosis induced by $\mathrm{CCl}_{4}$. These activities were assessed by investigating the liver enzymes ALT, AST, and Alb. Also, biochemical markers: TGF $\beta-1$, HA, IL-6 level, and immunohistological markers PCNA and $\alpha-$ SMA analysis were observed and then compared and statically represented. A randomized controlled trial was applied on 21 mice that were grouped into 3 groups. The control group received water and standard feed. A positive control group took $\mathrm{CCl}_{4}(0.5 \mu \mathrm{l} / \mathrm{g})$ only. Therapeutic group took $\mathrm{CCl}_{4}(0.5 \mu \mathrm{l} / \mathrm{g})$ then quercetin $(50 \mathrm{mg} / \mathrm{kg})$. Increases in ALT, AST, and biochemical markers (TGF $\beta-1$, HA, IL-6) activities and decrease in $\mathrm{Alb}$ were observed in mice who received $\mathrm{CCl}_{4}$ only, in contrast to mice that took quercetin after $\mathrm{CCl}_{4}$ administration with statistically significant value $\mathrm{p}<0.001$. After receiving quercetin, the immunohistological investigation assessed $\alpha$-SMA downregulation, which certain ECM accumulation, but a renewal of fibrotic liver cells was detected with the raise of the regenerative marker PCNA within the liver cells. Quercetin extracted from broccoli may assist in the therapy and improving the recovery of the fibrotic liver.
\end{abstract}

Keywords: Quercetin; $\mathrm{CCl}_{4}$; liver fibrosis; HSCs activation; broccoli; antifibrotic effect; TGFB-1; IL6; PCNA.

(c) 2020 by the authors. This article is an open-access article distributed under the terms and conditions of the Creative Commons Attribution (CC BY) license (https://creativecommons.org/licenses/by/4.0/).

\section{Introduction}

The fibrotic liver is a dangerous disease, being categorized as the main reason for mortality. It often ends with aggressive diseases like ascites, cirrhosis, and hepatocellular carcinoma [1]. Liver fibrosis results from chronic pro-inflammatory injuries that cause hepatocellular damage and triggering distorted liver parenchymal regeneration and fibrous tissue accumulation [2]. Liver viruses $\mathrm{B}$ and $\mathrm{C}$, fatty hepatopathy, autoimmune hepatitis, excessive drinking of alcohol are the most common causes of liver fibrosis in the whole world [3]. Egypt has $15 \%-25 \%$ of the population in adults who suffered from hepatopathy due to virus $\mathrm{C}$ infection, mostly in fibrosis of hepatic cells [4]. Although the main method for detecting and staging liver fibrosis is liver biopsy, which is expensive, invasive, and with a high risk of complications, we urgently need different techniques to diagnose hepatic fibrosis, such as serum biomarkers "noninvasive technique" [5]. The liver is involved in oxidative and 
detoxifying processes mainly and free radical reactions. Therefore, as in various diseases, oxidative stress biomarkers are high in hepatopathy [6]. Carbon tetrachloride $\left(\mathrm{CCl}_{4}\right)$ is a potent hepatotoxic that mimics oxidative stress in various diseases [7]. $\mathrm{CCl}_{4}$ treatment causes severe hepatopathy through a substantial increment in the blood levels of hepatic biochemical markers like ALT and AST [8,9]. The fibrosis of hepatic cells is marked with increased extracellular matrix(ECM) accumulation in the interstitial, resulting in stiffness and loss of the liver's function and architecture [10]. Many growth factors, chemokines, cytokines contribute to the progress of fibrosis, such as transforming growth factor beta-1 (TGF $\beta-1)$, Interleukin-6 (IL-6), and Hyaluronic acid( HA). TGF $\beta$ is a ubiquitous and potent pro-fibrogenic cytokine raised in almost all fibrotic diseases in experimental fibrosis models.

Any disturbances in the production of TGF $\beta$ induces liver fibrosis [11,12]. Quercetin is a common flavonoid widely present in different plants, including broccoli [13], apples, citrus fruits, onions, berries, and tomatoes [14]. Quercetin helps living organisms due to its antifibrotic, -antioxidant, and anti-inflammatory effects [15]. In general, any chemical agents that target liver fibrosis can achieve their activities in three different ways; Fibro-preventive agent reduces hepatic cell damage by protecting liver cells from damage and inducing the removal of the noxious agent. Fibrostatic agents induce interfering with HSCs transdifferentiation and result in the reduction of the undesired new matrix formation. The last fibrinolytic agent promotes fibrosis resolution by inducing necrosis and apoptosis of MFBs [16]. In our research, we have the antifibrotic quercetin as a fibro-preventive agent to reduce liver cell damage and as a fibro-static agent to suppress the new matrix's production. Quercetin contributes to improving liver diseases due to their anti-inflammatory properties [17]. In our research, we detected the antifibrotic quercetin extracted from broccoli by investigating related alteration in biomarkers, and immunohistological markers confirmed by statistical analysis.

\section{Materials and Methods}

\subsection{Chemicals and KITS.}

Basal diets, analytical grade carbon tetrachloride $\left(\mathrm{CCl}_{4}\right)$, were sourced from ElGomhouria Company, Zagazig, Egypt. Broccoli was from the local market in Zagazig, Egypt. The herbarium unit of Botany Department Faculty of Science, Zagazig University, proved and identified the plant. From Fisher Scientific, UK, we collected HPLC grade chemicals (Ethanol, Methanol, and $\mathrm{HCl}$ ). Quercetin (standard for HPLC analysis) was sourced from Sigma (St. Louis, MO, USA). Chemical kits for ALT and AST were from Spectrum Diagnostic, Cairo/Egypt. Albumin kit was from Biodiagnostic company, Giza/Egypt, TGF $\beta$-1and HA kits were from Cusabio, Wuhan, China, (IL-6) was from Beijing 4A Biotech Co., Ltd. China, $\alpha-$ SMA and PCNA monoclonal antibodies were from Dako Ltd.(Glostrup, Denmark).

\subsection{Experimental design.}

\subsubsection{Preparation of standard Quercitin solution.}

Quercetin standard solution $(200 \mathrm{ug} / \mathrm{ml})$ was made by adding an accurate mass of $20 \mathrm{mg}$ of quercetin into $100 \mathrm{ml}$ methanol [18]. 


\subsubsection{Sample preparation and Quercitin extraction.}

The plant material $\left(2 \mathrm{~kg}\right.$ of broccoli) was immediately deep-frozen at $\left(-40^{\circ} \mathrm{C}\right)$, then freeze-dried and finely ground. Quercetin was extracted successfully from each $200 \mathrm{mg}$ of broccoli plant in a freeze-dried form as following; at first, $\mathrm{HCl}$ solution (ethanol/water/HCl, $50: 20: 8, \mathrm{v} / \mathrm{v} / \mathrm{v})(12 \mathrm{~mL})$ at $90{ }^{\circ} \mathrm{C}$ for $60 \mathrm{~min}$ was added to the plant to be hydrolyzed. Every 15 min shakes the sample solutions. The extract of broccoli was increased to $25 \mathrm{~mL}$ with methanol. We filtered a sample $(15 \mathrm{ml})$ into a $0.45 \mu \mathrm{m}$ polyvinylidene fluoride (PVDF) membrane filter Before the High-performance liquid chromatography (HPLC) analysis [19]. The liquid sample was poured into a $(7 \mathrm{~mm})$ Petri dishes, frozen at $-20^{\circ} \mathrm{C}$, and lyophilized at $-55{ }^{\circ} \mathrm{C}$ under vacuum for $48 \mathrm{~h}[20]$.

\subsection{Animals in total.}

21 Swiss albino, adult male mice weighing around 20-25 g were sourced from Animal House of the National Research Center (NRC), Dokki, Giza, Egypt, were kept in a stable environment with relative humidity $(80 \% \pm 5 \%)$, [temperature $\left(23^{\circ} \mathrm{C} \pm 2^{\circ} \mathrm{C}\right)$, and light $(12 \mathrm{~h}$ light/dark cycles)], and were put in cages with wire mesh. Mice were feeding on a common laboratory diet and drinking water. All experiments were done, likewise the guidelines for animal studies issued by the Faculty of Science Ethical Committee, ZAGAZIG University, as approved by the Institutional Animal Care and Use Committee (ZU-IACUC) Ethics Reference Number (ZU-IACUC /1/F/52/2018).

\subsection{Treatments of mice.}

The mice acclimatized for one week, then they were grouped into 3 groups $(n=7)$. The control group was fed on water and standard feed for 8 weeks; the positive control group $\mathrm{CCl}_{4}$ got $\mathrm{CCl}_{4}(0.5 \mu \mathrm{l} / \mathrm{g})$ [21,22], i.p twice weekly in corn oil (1:3) only for the first 4 weeks and normal diet for the following 4 weeks; the therapeutic group $\left(\mathrm{CCl}_{4}+\mathrm{Q}\right)$ received $\mathrm{CCl}_{4}(0.5 \mu \mathrm{l} / \mathrm{g})$ i.p twice weekly in corn oil (1:3) for 4 weeks, then got quercetin (Q) $(50 \mathrm{mg} / \mathrm{kg})$ in saline daily by oral gavage for the following 4 weeks[17,23,24].

\subsection{Blood sampling.}

After the practical steps were completed, we used an intraperitoneal sodium pentobarbital injection to euthanize all mice for the autopsy. From the inferior vena cava of all mice, we collected the blood samples in normal glass tubes without heparin and kept them to clot at room temperature for $30 \mathrm{~min}$. Then, for $20 \mathrm{~min}$, the clotted samples' tubes were separated by centrifuging at $5000 \mathrm{rpm}$. After separation of all the blood samples' serum, we kept them at $-80^{\circ} \mathrm{C}$ until required. Before assay, at room temperature, samples were liquefied to perform the analysis of the biochemical marker.

\subsection{Histopathological studies.}

Livers were taken from all mice. Then were washed with the normal saline solution and immediately preserved in neutral buffered formalin (10\%) for 48 hours. Then they were processed in an automated tissue processor. After we purified the samples in various xylene changes, the samples were saturated with wax or paraffin, then were submerged and sealed. We stained paraffin sections $(4-5 \mu \mathrm{m})$ with hematoxylin and eosin $[25,26]$. Finally, samples 
were examined for inflammation, circulatory disturbances, degenerations, apoptosis, any pathological changes, and necrosis.

\subsection{Statistical analysis.}

We applied the Social Sciences SPSS 14.0 version using T-test (2- tailed) for performing our data to compare between groups and one-way analysis of variance (ANOVA) according to Levesque [28], followed by posthoc test using Graph pad Prism-5 software. Numerical data were expressed as mean \pm SEM. P-value $<0.001$ was considered significant.

\section{Results and Discussion}

\subsection{Results.}

3.1.1. Extraction of quercitin from broccoli.

The total plant sample ( $2 \mathrm{~kg}$ ) gives us $(220 \mathrm{mg}$ ) of quercetin as a powder, which is identified using High-Performance Liquid Chromatography (HPLC) (Figure 1).
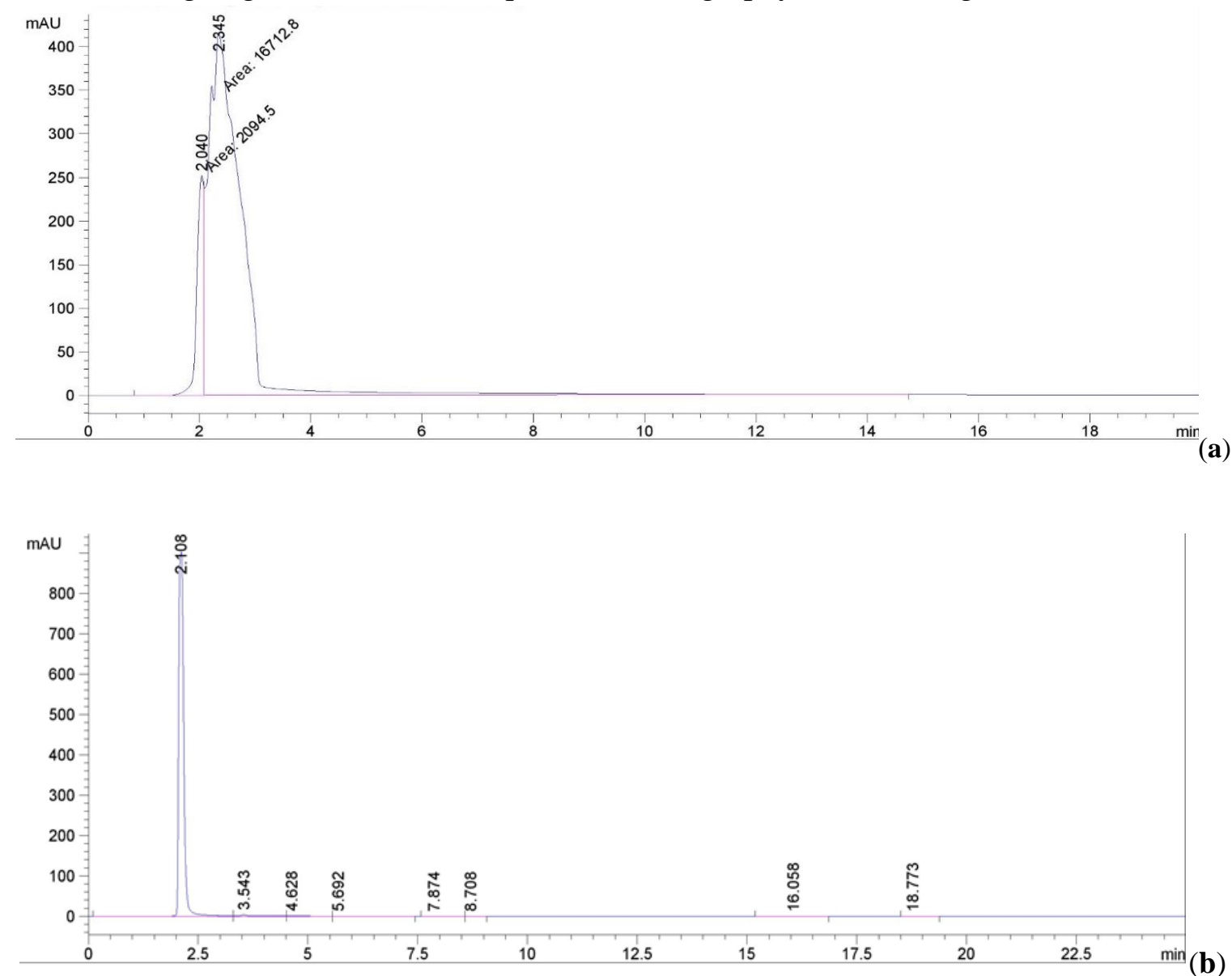

Figure 1. HPLC chromatogram for quercetin (a) HPLC chromatogram for extracted quercetine; (b)HPLC chromatogram for standard quercetin.

3.1.2. Effect of quercitin on biochemical variables in all groups.

There was a significant decrease in the level of ALT, AST, TGFB-1, IL-6 \& HA, in addition to an increase in albumin level in the therapeutic group compared to the positive control group as shown in Table $1 \&$ Figure 2. 
Table 1. Effect of quercetin on biochemical variables in all groups for observation of therapeutic activity.

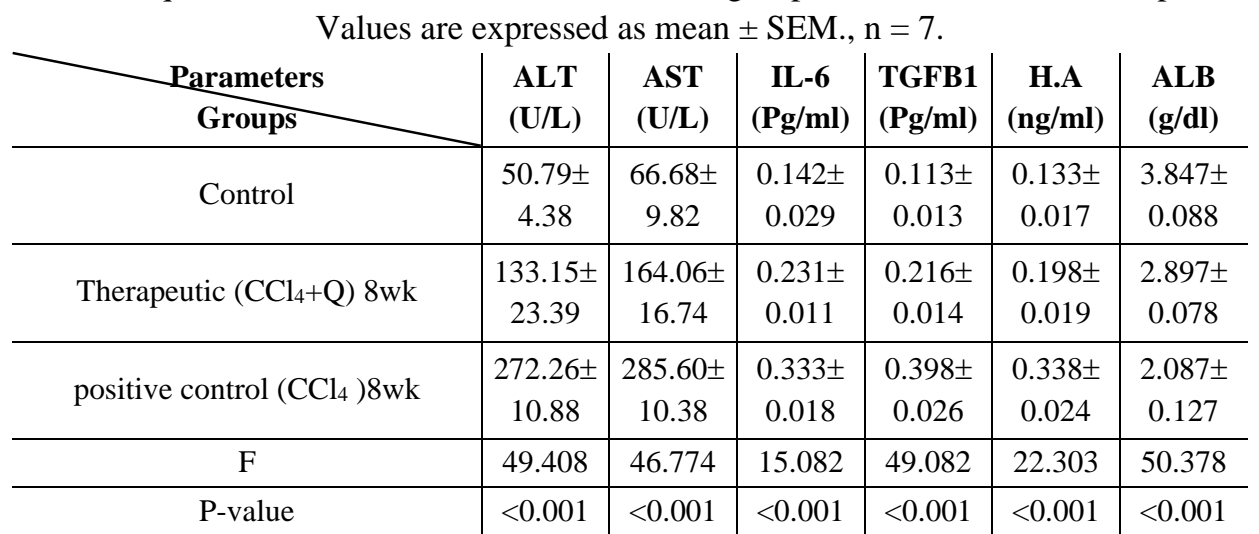

- values of biochemical variables between control and positive control $\left(\mathrm{CCl}_{4}\right)$ were compared to reveal the impact of $\mathrm{CCl}_{4}$ on the level of biochemical parameters; indicates $p<0.001$;

- values of biochemical variables between positive control $\left(\mathrm{CCl}_{4}\right)$ and therapeutic $\left(\mathrm{CCl}_{4}+\mathrm{Q}\right)$ were compared to reveal the therapeutic impact of quercetin on $\mathrm{CCl}_{4}$-induced liver fibrosis to show a statistically significant value $p<0.001$.

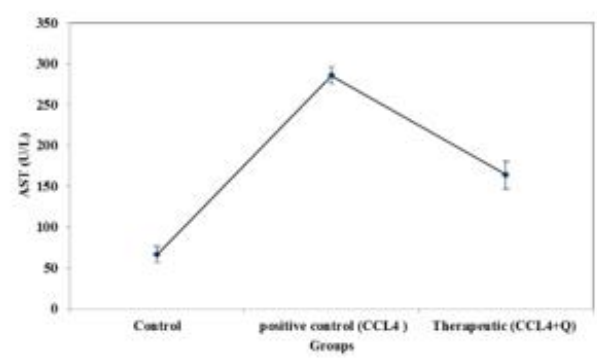

(a)

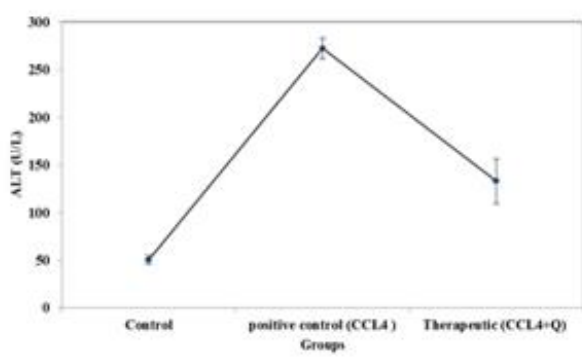

(b)

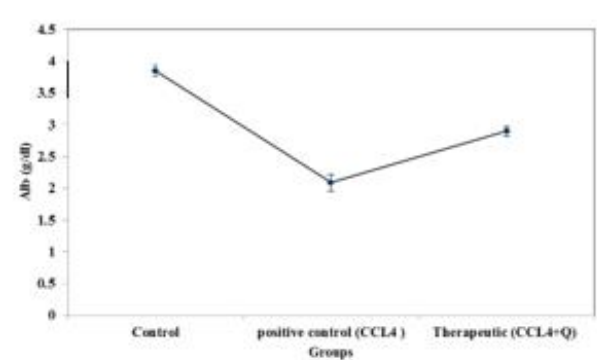

(c)

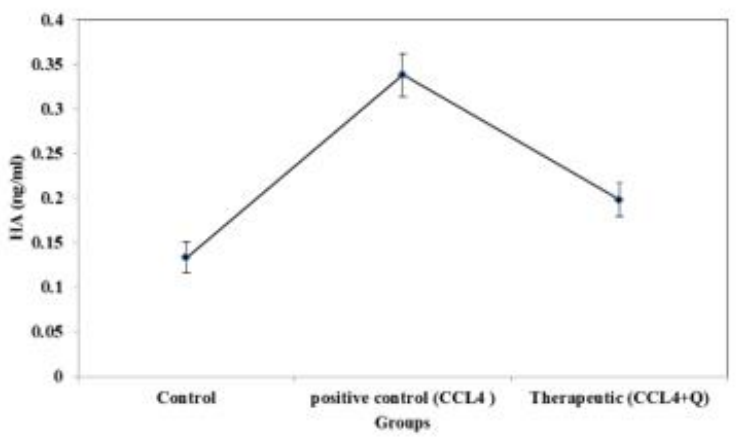

(e)

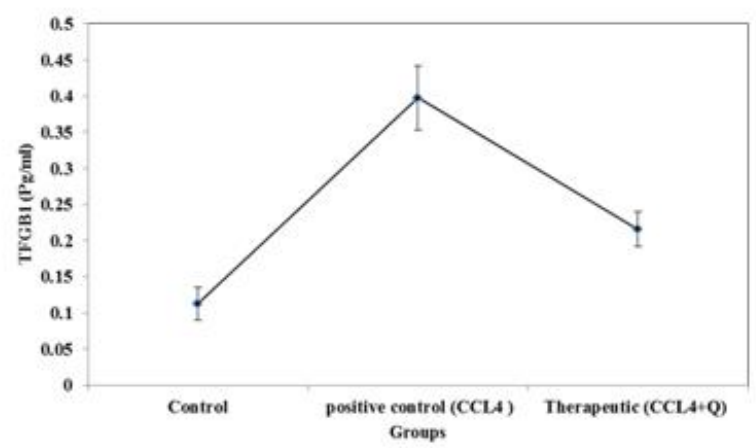

(d)

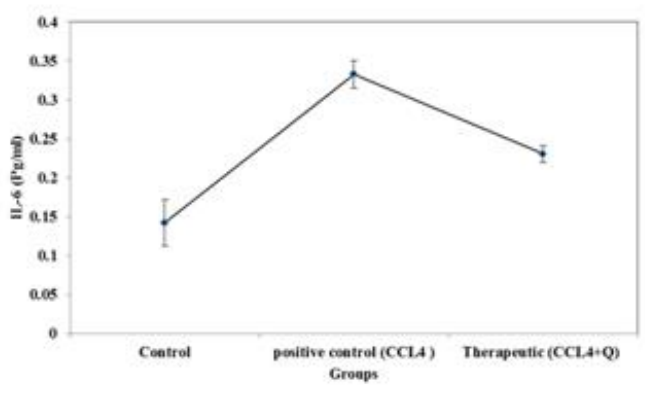

(f)

Figure 2. Activities of all biochemical variables in the groups; (a) AST activity in the groups; (b) ALT in groups activity; (c) Alb activity in the groups ; (d) TGFB-1 activity in the groups; (e) H.A. activity in the groups ; (f) IL-6 activity in the groups. 
3.1.3. Histopatological study.

Control group with normal parenchyma of liver cells, preserved lobular pattern, portal area, sinusoids, hepatic cords arrangement, and stroma (Plate 1).

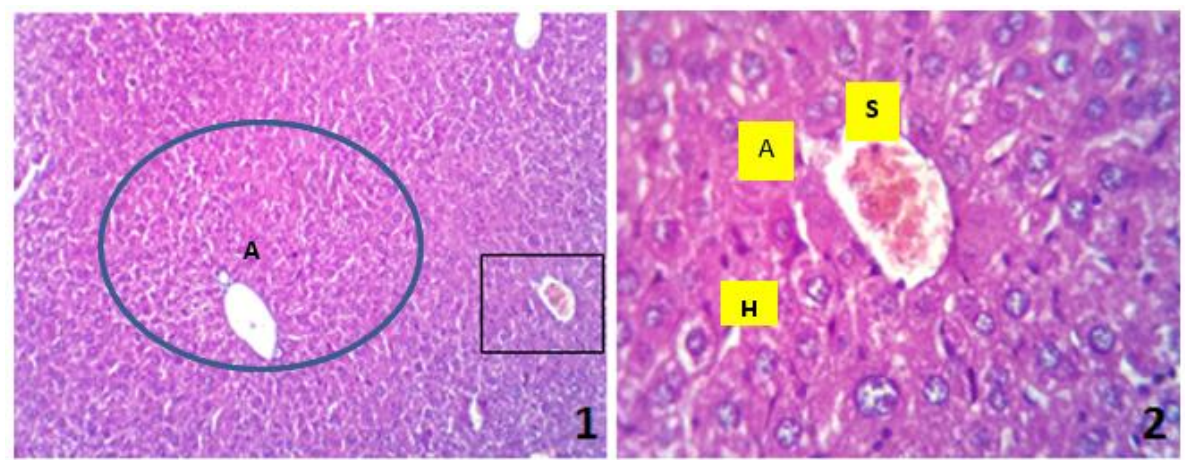

Plate 1. Photomicrograph of liver showing normal hepatic parenchyma with preserved lobular pattern (circle \& squire) central veins (A), portal area, sinusoids (S), hepatic cords (H)arrangement and stroma. H\&E X 100 (1), $400(2)$.
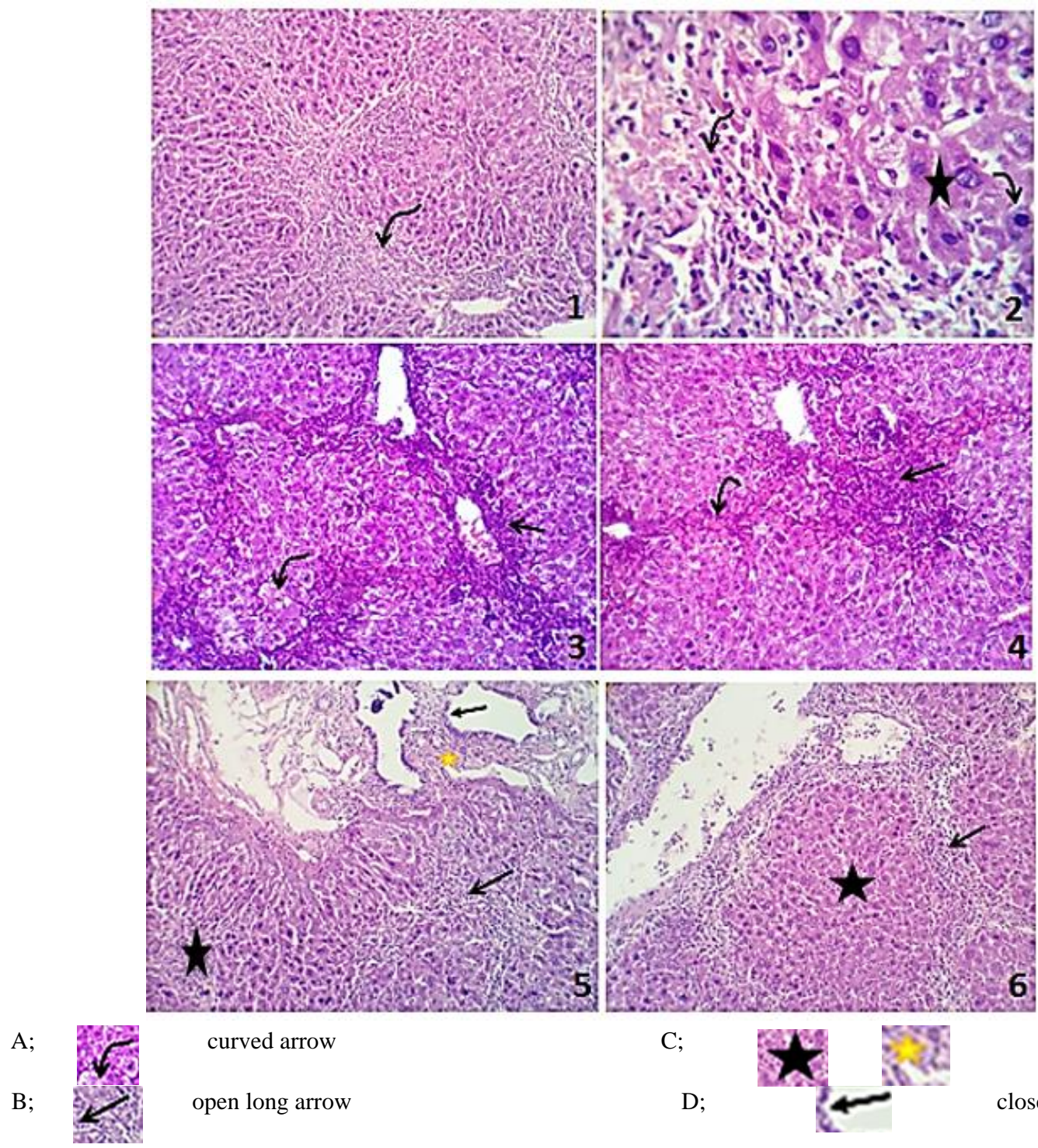

curved arrow

open long arrow

$\mathrm{C}$;

$\mathrm{D}$

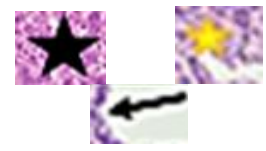

stars

closed short arrow

Plate 2. Photomicrograph of liver showing moderate periportal degenerative and necrotic changes (3, curved arrows $)^{\mathrm{A}}$; accompanied by intense portal inflammatory reaction with fibroblastic hyperplasia (1,2 curved arrow,

3,4,5,6 long open arrow $)^{\mathrm{B}}$; some hepatocytes showed compensatory regenerative changes $\left(\right.$ stars $^{\mathrm{C}}$; besides adenomatous biliary hyperplasia (5, closed short arrow ) ${ }^{\mathrm{D}}$; H\&E X $100(1,3,6), 200(4,5)$ 400(2). 
The positive control $\left(\mathrm{CCl}_{4}\right)$ group: Identical feature of sub-acute $\mathrm{CCl}_{4}$ toxicity represented by moderate periportal hepatocytes. Degenerative and necrotic changes accompanied by intense portal inflammatory reaction followed by fibroblastic hyperplasia formed strands enclosing hepatic lobules. Some hepatocytes showed compensatory regenerative changes as they were large in size with large hyperchromatic and/or double nuclei. Adenomatous biliary hyperplasia was also seen (Plate 2$)$. The therapeutic $\left(\mathrm{CCl}_{4}+\mathrm{Q}\right)$ group liver showed a moderate inflammatory reaction in the portal area with mixed populations of cells, including lymphocytes, macrophages, and few neutrophils, besides mild biliary proliferation. The hepatocytes were normal with mild vacuolar and hydropic degenerations in a few of them (Plate 3).
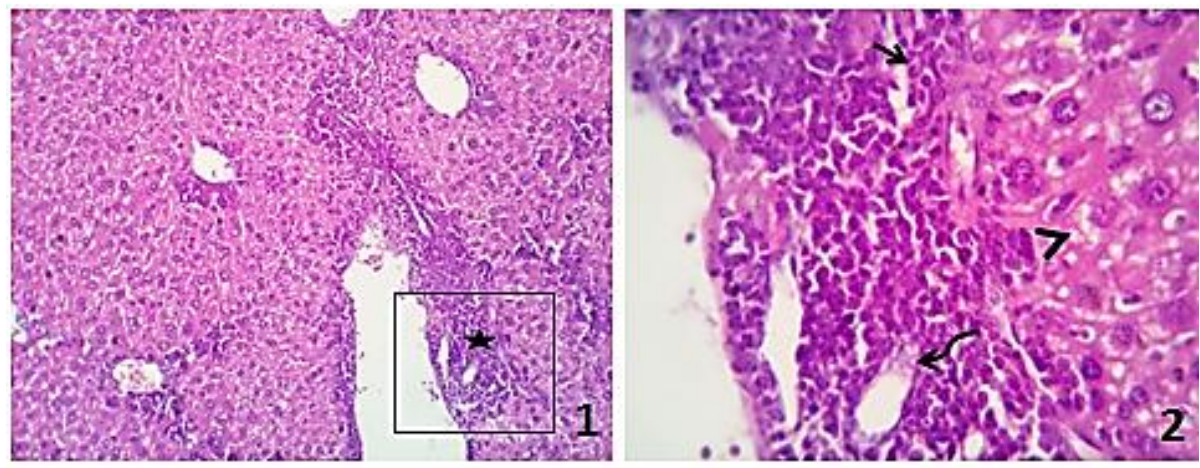

Plate 3. Photomicrograph of liver showing moderate inflammatory reaction in the portal area (star) with mixed cell populations including lymphocytes, macrophages, and few neutrophils (open arrow) besides mild biliary proliferation (curved arrow). Some hepatocytes showing vacuolar (arrowhead). H\&E X 100 (1), 400 (2).

\subsubsection{Immunohistochemical study.}

3.1.4.1. Determination Alpha smooth muscle actin ( $\alpha$-SMA) ( Fibrogenic marker).

The Control group showed Mild to moderate reactivity( brownish stainability) for the alpha-smooth muscle actin in the perisinusoidal tissue. (Plate 4). A positive control group $\left(\mathrm{CCl}_{4}\right)$ showed High reactivity for the marker in the perisinusoidal tissue and around portal blood vessels and capillaries. Proliferating fibroblasts in the portal area showed intense brownish reactivity to the collagen fibers (Plate 5). The therapeutic $\left(\mathrm{CCl}_{4}+\mathrm{Q}\right)$ group showed mild to moderate reactivity in the perisinusoidal tissue, contrary to the control free group (Plate 6).

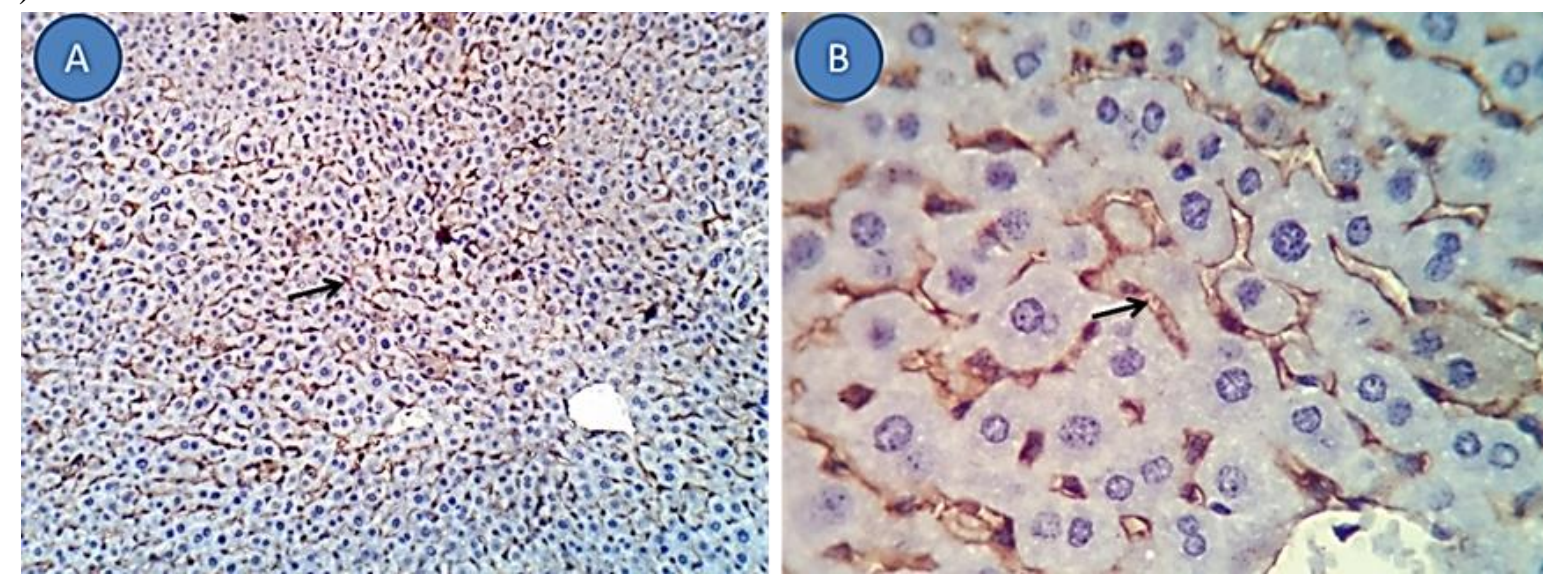

Plate 4. Photomicrograph of control group liver showing (1) mild to moderate reactivity (brownish stainability) for the alpha-smooth muscle actin in the perisinusoidal tissue (arrows). (2) high magnification of fig.1. X 100(A), 400( B). 

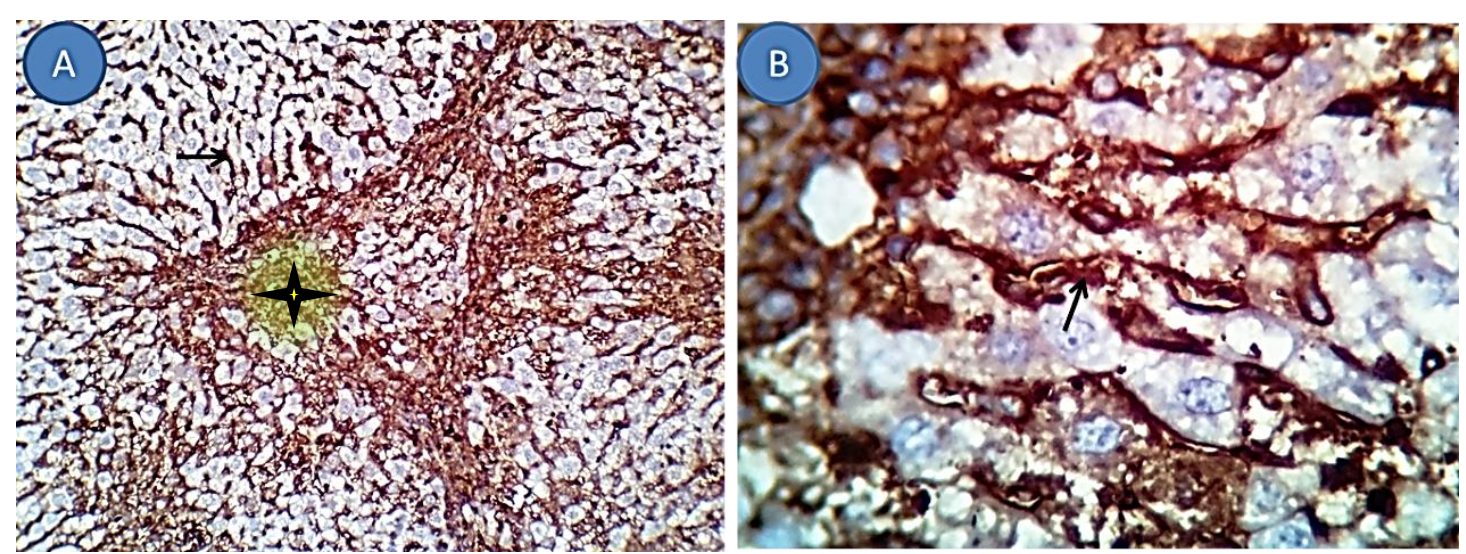

Plate 5. Photomicrograph of positive control $\left(\mathrm{CCl}_{4}\right)$ group: liver showing high reactivity for the marker in the perisinusoidal tissue(B, arrow), around portal blood vessels and capillaries the collagen of proliferating fibroblasts. (A, star). X 100(A), 400(B).
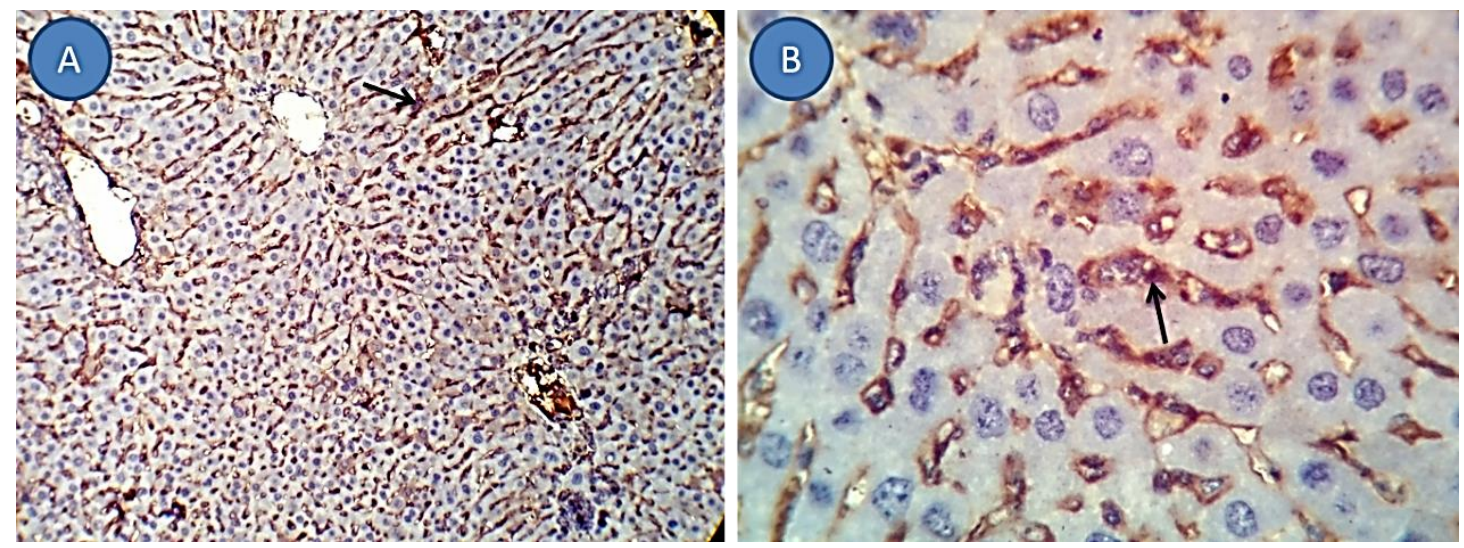

Plate 6. Photomicrograph of therapeutic $\left(\mathrm{CCl}_{4}+\mathrm{Q}\right)$ group: liver showing mild to moderate reactivity in the perisinusoidal tissue contrary to the control free group (arrows). X 100(A), 400(B).

\subsubsection{Proliferating cell nuclear antigen (PCNA).}

The sections examined from the control group revealed negative nuclear and cytoplasmic reactivity in almost all hepatic and stromal cells. (Plate 7). The sections examined from the positive control $\left(\mathrm{CCl}_{4}\right)$ group showed low reactivity in most hepatocytes. A few regenerating hepatocytes around the portal area appeared strongly positive for PCNA. (Plate 8). The therapeutic $\left(\mathrm{CCl}_{4}+\mathrm{Q}\right)$ group appeared a moderate number of regenerating hepatocytes, particularly around the portal area, showing a strong positive cytoplasmic and/or nuclear brownish (Plate 9).
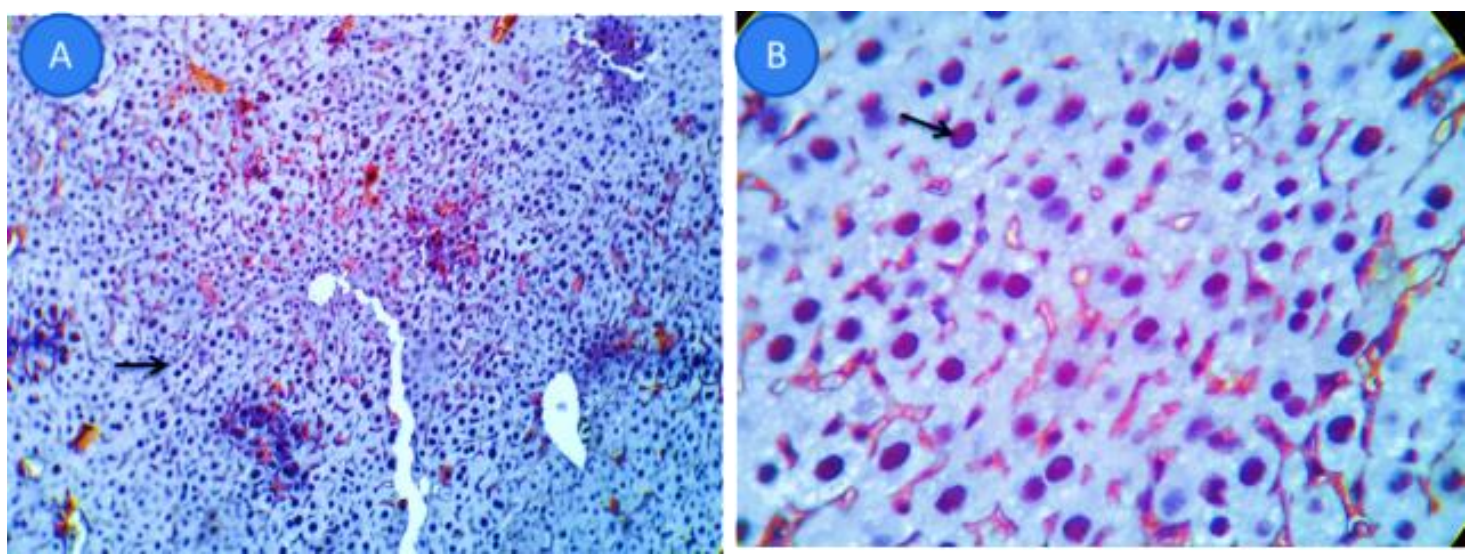

Plate.7. Photomicrograph of control group liver showing negative nuclear and cytoplasmic reactivity for PCNA. (arrows). X 100 (A), 400 (B). 

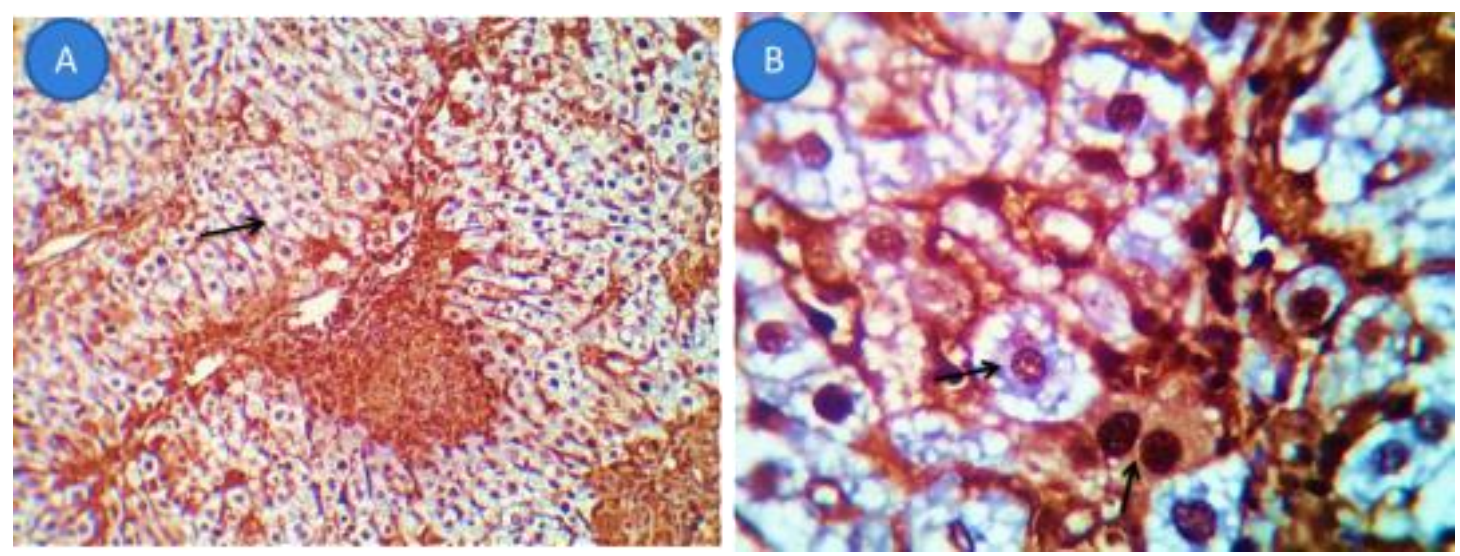

Plate 8. Photomicrograph of positive control $\left(\mathrm{CCl}_{4}\right)$ group liver showing low reactivity to PCNA as a few regenerating hepatocytes around the portal area appeared strongly positive (green star). Normal hepatocytes appear negatively stained (A, B, arrows) X 100 (A), 400(B).
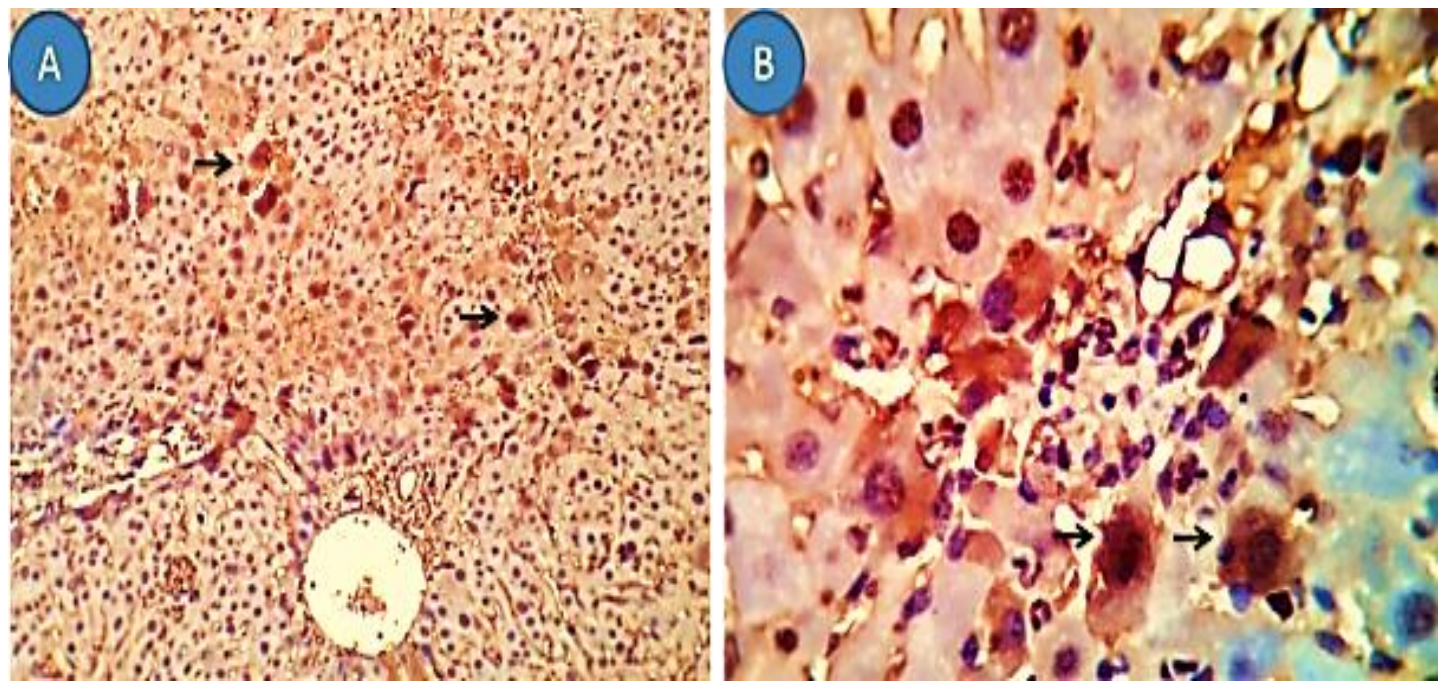

Plate 9. Photomicrograph of therapeutic $\left(\mathrm{CCl}_{4}+\mathrm{Q}\right)$ group: liver showing a moderate number of regenerating hepatocytes, particularly around the portal area with a strong positive cytoplasmic and/or brownish nuclear stainability. (arrows). X 100 (A), 400(B).

\subsection{Discussion.}

Fibrosis of liver cells is generated from wound healing, which is enhanced by liver injury and inflammation, it is related to remodeling of ECM [16,29]. $\mathrm{CCl}_{4}$ is a hepatotoxin used to stimulate chronic hepatopathy through two phases: The first is $\mathrm{CCl} 4$ metabolism using CYP450 to be converted to $\mathrm{CCl}_{3}$ and /or $\mathrm{CCl}_{3} \mathrm{OO}$ cause peroxidation of the lipid in the hepatic cellular membrane and finally result in necrosis of the hepatocytes. The secretion of important inflammatory stimulants such as TGF $\beta-1$ and IL- 6 is induced after the activation of Kupffer cells is considered the second phase [18,30]. This is compatible with our data in Table 1, which showed that $\mathrm{CCl}_{4}$ treatment resulted in overexpression of TGF $\beta$-1 and IL-6, also matching with Ragb et al., who found that the reason for $\mathrm{CCl}_{4}$ oxidative stress resulted in changes of biochemical markers, hepatic cellular DNA, and antioxidant status [31]. Quercetin is a wellknown flavonoid available in natural plants, including broccoli [13]. Quercetin is known to have different activities, including antioxidant, antiviral, anti-inflammatory, anti-proliferative, and antifibrotic effects [17]. The impact of quercetin on the fibrotic liver was reported in various studies, which are compatible with our study findings, which investigated the hepatic antifibrotic impact of quercetin extracted from broccoli in experimental $\mathrm{CCl}_{4}$ fibrosis mice model $[32,33]$. In our research, we extracted quercetin from broccoli, according to Nishimuro 
et al. and Cheaib et al. [19,20]. High-performance liquid chromatography (HPLC) indicated the extracted quercetin. This is like the previous studies that certain HPLC is the most important technique for Quercetin determination in various matrices [34,35]. The effect of any hepatoprotective agent is measured by its capacity to control the important physiological pathways which may found in the liver that perhaps be interrupted by different toxins or by its role in eliminating any possible damage in the liver. In our research, the hepatic antifibrotic impact of quercetin extracted from broccoli was obvious in modulating the value of biochemical markers characteristic of hepatic fibrosis. Liver enzymes, such as (AST) and (ALT), are common indicators for hepatic injury, but indirectly they show the functional status of the liver [9,36]. Our data in Table (1) presented a significant rise of (ALT and AST) that assed $\mathrm{CCl}_{4}$ caused severe hepatopathy. The relief of these enzymes after treatment with quercetin is an indication of liver preservation. Also, Khodarahmi et al. found a raised level of AST and ALT in the bile duct ligation animals. However, they decreased after quercetin treatment [37]. The liver is responsible for producing the most serum proteins in the body, such as serum Albumin [38]. The decrease in Alb level usually appears because of direct arresting the liver pathway of Alb-synthesizing, inflammation, and impaired hepatic function [39]. $\mathrm{CCl}_{4}$ decreases the total serum protein because of its role in inducing the apoptosis of normal liver cells, resulting in reducing the liver's ability to produce serum proteins [40]. Our present study showed a significant lowering in serum albumin due to hepatotoxicity by $\mathrm{CCl}_{4}$. It reflected the hepatic protective effect of extracted quercetin by increasing the albumin level. Also, found that quercetin increased the level of Alb in injured livers towards normal values [41]. TGF $\beta-1$ is an available fibrogenic mediator in response to cellular injury that induces ECM production and apoptosis[42]. Studies in which TGF $\beta-1$ is overexpressed in the liver have revealed that TGF $\beta$ - 1 contributes to HSCs activation and liver fibrogenesis. Furthermore, blocking of TGF $\beta$ 1 signaling protected mice and rats against fibrosis of hepatic cells in several experimental models $[12,43]$. TGF $\beta$ is synthesized in the form of the inactive precursor as a large latent complex, which cannot bind to its receptors until being activated after hepatopathy, either by enzymatic proteolysis, executed by plasmin, integrin, or thrombin or through a conformational change [44]. Most liver cells produce the large latent TGF-beta complex, such as Kupffer cells, liver sinusoidal endothelial cells, dendritic cells, hepatic lymphocytes [45], and quiescent HSCs also myofibroblasts (MFBs) [12]. The large latent TGF $\beta$ complex will be deposited in the surrounding ECM [46]. During liver injury, TGF $\beta$ is triggered from deposits in the ECM, and become free from various liver cell types. Activated TGF $\beta$ target quiescent HSC to be activated and differentiated into MFB [29]. As it was reported in previous studies hepatocytes did not synthesis the large latent TGF $\beta$ complex, but they absorbed and released it into the immediate microenvironment by membrane injury in its active form $[47,48]$. When damaged hepatocytes release the activeTGFB-1, it starts the main signal for adjacent HSCs that result in their activation and transdifferentiation to MFBs Furthermore, TGF- $\beta$ induces the fibrogenesis process $[49,50]$.In this study, $\mathrm{CCl}_{4}$ elevated TGF $\beta-1$ level in the positive control group but extracted quercetin had a significant decrease in the elevation of TGF $\beta-1$ in the therapeutic group because of its antifibrotic and anti-apoptotic effect. This is in concordant with those who declared that treatment with quercetin had significantly reduced the $\mathrm{CCl}_{4}$ elevated TGF $\beta-1$ [51]. Also, assert that quercetin inhibits the TGFB-1 pathway [52].

Different kinds of hematopoietic somatic cells secrete a pleiotropic cytokine IL-6 [53]. $\mathrm{CCl}_{4}$ treatment induces IL-6 production from IL-6 producer cells such as Kupffer cells, fibroblasts, and endothelial cells. IL-6 affects liver cells, especially lipocytes, and increases 
collagen synthesis extracellular matrix accumulation, leading to hepatic fibrosis [54-56]. IL-6 also play important role in HSCs activation [57]. in our research work, Il-6 was raised in $\mathrm{CCl}_{4}$ received group and decreased in extracted quercetin treated groups. Our outcomes are in line with those who stated that fibrosis was improved after quercetin's treatment by interrupting the release of IL-6 [33]. Activated HSCs form $5 \%-8 \%$ of cells in the normal liver [58]. In the normal liver, quiescent HSCs are the major stocking site for a retinoid. After hepatopathy for any reason, HSC receives a sign of activation from profibrogenic cytokine such as TGFB-1 IL6 , which is a change the latent cells into a myofibroblast-like cell secreting matrix proteins [59]. Overabundant and maladaptive generation of the matrix also connective tissue synthesis and deposition during fibrogenesis, are controlled by activated hepatic stellate cells $[29,60]$. $\alpha$ smooth muscle actin ( $\alpha$-SMA) is a microfilament intracellular protein produced by activated HSCs, so its presence represents evidence of activation of hepatic stellate cells [61,62]. In our present study, it was found that positive control staining for $\alpha$-SMA was markedly positive immunostaining in $\mathrm{CCl}_{4}$-model mice in the perisinusoidal tissue, interestingly the cytoplasm of some periportal necrotic hepatocyte and collagen of proliferating fibroblasts and around portal blood vessels and capillaries when compared with a negative control that has no evidence of immunostaining for $\alpha$-SMA. Our data also demonstrated that $\alpha$-SMA significantly decreased by administering extracted quercetin there was weekly positive immunostaining for $\alpha$-SMA. These findings are like those who elucidated that $\mathrm{CCl}_{4}$ treatment significantly increased $\alpha$ SMA, but the treatment of quercetin decreased $\alpha$-SMA [63].

As it was demonstrated, $\mathrm{CCl}_{4}$ treatment resulted in increased expression of TGF $\beta$ - 1 and IL-6, which are pro-inflammatory cytokines, they are largely involved in the activation of portal fibroblasts, particularly hepatic stellate cells (HSCs), which have been identified as major cells that produce collagen in the injured liver, playing the main role in the synthesis of fibrous tissue and extracellular matrix components [64]. Hyaluronic acid (HA) is a glycosaminoglycan and is the basic component of ECM [65], mostly synthesized by HSCs. In a healthy liver HA most uptake and degradation take place in hepato-sinusoidal endothelial cells. Increased HA concentrations in serum are attributable to increased production or decreased hepatic elimination, or both [66]. Stages of fibrosis also necrosis of liver cells, and inflammation are closely linked with a rise in serum HA [67]. The liver fibrosis stage is more correlated with HA level contrary to AST, platelet count, ALT, albumin, total bilirubin, alkaline phosphatase, and prothrombin time [68]. In our findings, HA levels were increased in $\mathrm{CCl}_{4}$ fibrotic model mice but were decreased by extracted Quercetin treatment. Our outcomes were in accordance with [63]. These findings asserted that quercetin is collaborated to arrest the HSCs activation, which decreases the producer cells of profibrogenic cytokines and extracellular matrix, which is reflected as a decrease of fibrosis and decreased liver cell death.

Proliferating cell nuclear antigen (PCNA) plays a significant role in cell regeneration because it contributes to important cellular physiological processes, such as DNA repair and replication [25]. Transforming growth factor beta-1 is a significant inhibitor of growth, regeneration, and proliferation of hepatic cells. TGF $\beta-1$ plays two roles: at an early stage of the diseases such as liver fibrosis plays its tumor-suppressive role because of its apoptotic effect, but at a later stage of liver diseases such as hepatocellular carcinoma, it plays its tumor enhancing roles due to the presence of a defect in TGF $\beta$ - 1 receptor processing on the liver cell membrane $[12,69]$. In this study, groups that got $\mathrm{CCl}_{4}$ appeared low reactivity in most hepatocytes for proliferative cellular marker PCNA, meaning a reduction in numbers of regenerating hepatocytes due to the apoptotic effect TGF $\beta-1$ that was induced by $\mathrm{CCl}_{4}$. 
However, groups treated with extracted quercetin exhibited medium reactivity in most hepatocytes for PCNA, which means an increase in numbers of regenerating hepatocytes. Our findings are compatible with the recent study, which showed that PCNA was less in the $\mathrm{CCl}_{4}$ group than in the therapeutic group [70]. The previous study also reported that overexpression of TGF $\beta-1$ inhibits growth in the cirrhotic liver could explain the lower PCNA immunopositivity observed as liver function decreases [71]. From these findings, we can say that quercetin extracted from broccoli contributed to improving liver regeneration. It increases the number of regenerating cells that show PCNA immunopositive staining. Histological findings of our research confirmed that quercetin improved all the pathological changes resulting from $\mathrm{CCl}_{4}$ induced hepatic fibrosis, which confirmed that quercetin improved hepatic cells regeneration and fibrosis also Li et al. stated that quercetin improved histological changes in hepatic fibrosis [33].

\section{Conclusions}

Quercetin extracted from broccoli played an anti-inflammatory, antifibrotic, and protective role in hepatopathy and liver fibrosis. Quercetin extracted from broccoli may be contributed to improving the hepatopathy by enhancing the renewal of the liver cells in fibrotic mice by repression of Transforming growth factor beta- 1 and profibrogenic cytokines, involved in arresting the migration and activation of hepatic stellate cells (HSCs), also attenuate the liver function enzymes, and ameliorate carbon tetrachloride $\left(\mathrm{CCl}_{4}\right)$ induced hepatic fibrosis.

\section{Funding}

The study did not receive specific grants from any agency in the commercial, public, or notfor-profit sector.

\section{Acknowledgments}

We appreciate Prof. Dr. Al-Sayed R. Al-Attar, Professor of Pathology, Faculty of Veterinary Medicine Zagazig University, who provided me the opportunity to explain and emphasize our results through the histopathological findings.

\section{Conflicts of Interest}

The authors declare no potential conflicts of interest concerning the research, authorship, and/or publication of this article.

\section{References}

1. Alsahhar, J.S.; Elwir, S. Epidemiology and Natural History of Chronic Liver Disease. In The Critically Ill Cirrhotic Patient: Evaluation and Management, Rahimi, R.S., Ed. Springer International Publishing: Cham, 2020; https://doi.org/10.1007/978-3-030-24490-3_1.

2. Hako, R.; Kristian, P.; Jarčuška, P.; Haková, I.; Hockicková, I.; Schréter, I.; Janičko, M. Noninvasive sResonance Imaging. Canadian Journal of Gastroenterology and Hepatology 2019, 2019, 3024630, https://doi.org/10.1155/2019/3024630.

3. Shipley, L.C.; Axley, P.D.; Singal, A.K. Liver Fibrosis: A Clinical Update. Hepatology 2019, 1, 105-117.

4. Fouad, S.A.; Esmat, S.; Omran, D.; Rashid, L.; Kobaisi, M.H. Noninvasive assessment of hepatic fibrosis in Egyptian patients with chronic hepatitis $\mathrm{C}$ virus infection. World journal of gastroenterology: WJG 2012, 18, 2988, https://dx.doi.org/10.3748\%2Fwjg.v18.i23.2988. 
5. Yilmaz, Y.; Eren, F. Serum biomarkers of fibrosis and extracellular matrix remodeling in patients with nonalcoholic fatty liver disease: association with liver histology. Eur. J. Gastroenterol. Hepatol. 2019, 31, 43-46, https://doi.org/10.1097/MEG.0000000000001240.

6. Benchouieb, I.; Rechreche, H.; Khennouf, T.; Lahouel, M. Assessment of carcinogenic benzo [a] pyrene acute toxicity involving oxidative stress in mice lung and liver. Algerian Journal of Environmental Science and Technology 2020, 6.

7. Rabiei, S.; Rezaie, M.; Abasian, Z.; Khezri, M.; Nikoo, M.; Rafieian-kopaei, M.; Anjomshoaa, M. The protective effect of Liza klunzingeri protein hydrolysate on carbon tetrachloride-induced oxidative stress and toxicity in male rats. Iranian Journal of Basic Medical Sciences 2019, 22, 1203-1210, https://doi.org/10.22038/ijbms.2019.33201.7927.

8. Elmowafy, E.; El-Derany, M.O.; Biondo, F.; Tiboni, M.; Casettari, L.; Soliman, M.E. Quercetin Loaded Monolaurate Sugar Esters-Based Niosomes: Sustained Release and Mutual Antioxidant-Hepatoprotective Interplay. Pharmaceutics 2020, 12, 143, https://doi.org/10.3390/pharmaceutics12020143.

9. Zein, N.; Abd Elghani, E.; Talat, E. Study The Effect of Coriandrum Sativumonliver Fibrosis Induced by Carbon Tetrachloride in Rats. I J A R 2015, 5, https://doi.org/10.36106/ijar.

10. Walraven, M.; Hinz, B. Therapeutic approaches to control tissue repair and fibrosis: Extracellular matrix as a game changer. Matrix Biol. 2018, 71, 205-224, https://doi.org/10.1016/j.matbio.2018.02.020.

11. Dewidar, B.; Meyer, C.; Dooley, S.; Meindl, B.; Nadja. TGF- $\beta$ in Hepatic Stellate Cell Activation and Liver Fibrogenesis-Updated 2019. Cells 2019, 8, 1419, https://doi.org/10.3390/cells8111419.

12. Fabregat, I.; Moreno-Càceres, J.; Sánchez, A.; Dooley, S.; Dewidar, B.; Giannelli, G.; Ten Dijke, P. TGF- $\beta$ signalling and liver disease. The FEBS journal 2016, 283, 2219-2232, https://doi.org/10.1111/febs.13665.

13. Mollica, A.; Stefanucci, A.; Zengin, G.; Locatelli, M.; Macedonio, G.; Orlando, G.; Ferrante, C.; Menghini, L.; Recinella, L.; Leone, S.; Chiavaroli, A.; Leporini, L.; Di Nisio, C.; Brunetti, L.; Tayrab, E.; Ali, I.; Musa, T.H.; Musa, H.H.; Ahmed, A.A. Polyphenolic composition, enzyme inhibitory effects ex-vivo and in-vivo studies on two Brassicaceae of north-central Italy. Biomed. Pharmacother. 2018, 107, 129-138, https://doi.org/10.1016/j.biopha.2018.07.169.

14. Mlcek, J.; Jurikova, T.; Skrovankova, S.; Sochor, J. Quercetin and its anti-allergic immune response. Molecules 2016, 21, 623, https://doi.org/10.3390/molecules21050623.

15. Ulusoy, H.G.; Sanlier, N. A minireview of quercetin: from its metabolism to possible mechanisms of its biological activities. Crit. Rev. Food Sci. Nutr. 2020, 60, 3290-3303, https://doi.org/10.1080/10408398.2019.1683810.

16. Weiskirchen, R.; Weiskirchen, S.; Tacke, F. Recent advances in understanding liver fibrosis: bridging basic science and individualized treatment concepts. Flo00Research 2018, 7, https://doi.org/10.12688/f1000research.14841.1.

17. Li, X.; Jin, Q.; Yao, Q.; Xu, B.; Li, Z.; Tu, C. Quercetin attenuates the activation of hepatic stellate cells and liver fibrosis in mice through modulation of HMGB1-TLR2/4-NF- $\mathrm{B}$ signaling pathways. Toxicol. Lett. 2016, 261, 1-12, doi:https://doi.org/10.1016/j.toxlet.2016.09.002.

18. Eidi, A.; Mortazavi, P.; Tehrani, M.E.; Rohani, A.H.; Safi, S. Hepatoprotective effects of pantothenic acid on carbon tetrachloride-induced toxicity in rats. EXCLI J 2012, 11, 748-759.

19. Nishimuro, H.; Ohnishi, H.; Sato, M.; Ohnishi-Kameyama, M.; Matsunaga, I.; Naito, S.; Ippoushi, K.; Oike, H.; Nagata, T.; Akasaka, H. Estimated daily intake and seasonal food sources of quercetin in Japan. Nutrients 2015, 7, 2345-2358, https://doi.org/10.3390/nu7042345.

20. Cheaib, D.; El Darra, N.; Rajha, H.N.; El-Ghazzawi, I.; Maroun, R.G.; Louka, N. Effect of the extraction process on the biological activity of lyophilized apricot extracts recovered from apricot pomace. Antioxidants 2018, 7, 11, https://doi.org/10.3390/antiox7010011.

21. Seki, E.; De Minicis, S.; Gwak, G.-Y.; Kluwe, J.; Inokuchi, S.; Bursill, C.A.; Llovet, J.M.; Brenner, D.A.; Schwabe, R.F. CCR1 and CCR5 promote hepatic fibrosis in mice. The Journal of Clinical Investigation 2009, 119, 1858-1870, https://doi.org/10.1172/JCI37444.

22. Yan, J.; Tung, H.-C.; Li, S.; Niu, Y.; Garbacz, W.G.; Lu, P.; Bi, Y.; Li, Y.; He, J.; Xu, M. Aryl hydrocarbon receptor signaling prevents activation of hepatic stellate cells and liver fibrogenesis in mice. Gastroenterology 2019, 157, 793-806, https://doi.org/10.1053/j.gastro.2019.05.066.

23. Abdalla, F.H.; Cardoso, A.M.; Pereira, L.B.; Schmatz, R.; Gonçalves, J.F.; Stefanello, N.; Fiorenza, A.M.; Gutierres, J.M.; da Silva Serres, J.D.; Zanini, D.; Pimentel, V.C.; Vieira, J.M.; Schetinger, M.R.C.; Morsch, V.M.; Mazzanti, C.M. Neuroprotective effect of quercetin in ectoenzymes and acetylcholinesterase activities 
in cerebral cortex synaptosomes of cadmium-exposed rats. Mol. Cell. Biochem. 2013, 381, 1-8, https://doi.org/10.1007/s11010-013-1659-x.

24. Mert, D.G.; Turgut, N.H.; Arslanbas, E.; Gungor, H.; Kara, H. The influence of quercetin on recognition memory and brain oxidative damage in a ketamine model of schizophrenia. Psychiatry and Clinical Psychopharmacology 2019, 29, 1-7, https://doi.org/10.1080/24750573.2018.1442670.

25. Layton, C.; Bancroft, J.D. Carbohydrates. In Bancroft's Theory and Practice of Histological Techniques, 7th Edition ed.; Elsevier: 2013; 215-238.

26. Mat-Rahim, N.A.; Lim, T.-H.; Nor-Amdan, N.-A.; AbuBakar, S. Hepatoprotective Effects of Chinese Medicine Herbs Decoction on Liver Cirrhosis in Rats. Evid. Based Complement. Alternat. Med. 2017, 2017, 6125829, https://doi.org/10.1155/2017/6125829.

27. Cheung, P.-Y.; Zhang, Q.; Zhang, Y.-O.; Bai, G.-R.; Lin, M.C.-M.; Chan, B.; Fong, C.-C.; Shi, L.; Shi, Y.F.; Chun, J. Effect of WeiJia on carbon tetrachloride induced chronic liver injury. World Journal of Gastroenterology: WJG 2006, 12, 1912, https://doi.org/10.3748/wjg.v12.i12.1912.

28. Levesque, R. SPSS programming and data management: a guide for SPSS and SAS users; Spss: 2005.

29. Tsuchida, T.; Friedman, S.L. Mechanisms of hepatic stellate cell activation. Nature Reviews Gastroenterology \& Hepatology 2017, 14, 397-411, https://doi.org/10.1038/nrgastro.2017.38.

30. Abdel-Moneim, A.M.; Al-Kahtani, M.A.; El-Kersh, M.A.; Al-Omair, M.A. Free Radical-Scavenging, AntiInflammatory/Anti-Fibrotic and Hepatoprotective Actions of Taurine and Silymarin against CCl4 Induced Rat Liver Damage. PLoS One 2015, 10, e0144509, https://doi.org/10.1371/journal.pone.0144509.

31. Ragab, G.M.A.; El-Denshary, E.S.; Hassan, A.M.; Abdel-Azeim, S.H.; Hassan, N.S.; Mannaa, F.A.; AbdelWahhab, M.A. Grape (Vitis vinifera) seed extract inhibits the cytotoxicity and oxidative stress in liver of rats treated with carbon tetrachloride. Global Journal of Pharmacology 2013, 7, 258-269, https://doi.org/10.5829/idosi.gjp.2013.7.3.7637.

32. Ganbold, M.; Shimamoto, Y.; Ferdousi, F.; Tominaga, K.; Isoda, H. Antifibrotic effect of methylated quercetin derivatives on TGF $\beta$-induced hepatic stellate cells. Biochemistry and Biophysics Reports 2019, 20, 100678, https://doi.org/10.1016/j.bbrep.2019.100678.

33. Li, X.; Jin, Q.; Yao, Q.; Xu, B.; Li, L.; Zhang, S.; Tu, C. The Flavonoid Quercetin Ameliorates Liver Inflammation and Fibrosis by Regulating Hepatic Macrophages Activation and Polarization in Mice. Front. Pharmacol. 2018, 9, 72, https://doi.org/10.3389/fphar.2018.00072.

34. Cortés-Herrera, C.; Artavia, G.; Leiva, A.; Granados-Chinchilla, F. Liquid chromatography analysis of common nutritional components, in feed and food. Foods 2019, 8, 1, https://doi.org/10.3390/foods8010001.

35. Soledad Garcia, M.; Isabel Albero, M.; Sánchez-Pedreño, C.; Abuherba, M.S. Spectrophotometric determination of cimetidine in pharmaceuticals and urine using batch and flow-injection methods. J. Pharm. Biomed. Anal. 2003, 32, 1003-1010, https://doi.org/10.1016/S0731-7085(03)00202-4.

36. Lala, V.; Goyal, A.; Bansal, P.; Minter, D. Liver function tests. StatPearls 2020. Available online: https://www.ncbi.nlm.nih.gov/books/NBK482489/.

37. Khodarahmi, A.; Eshaghian, A.; Safari, F.; Moradi, A. Quercetin Mitigates Hepatic Insulin Resistance in Rats with Bile Duct Ligation Through Modulation of the STAT3/SOCS3/IRS1 Signaling Pathway. J. Food Sci. 2019, 84, 3045-3053, https://doi.org/10.1111/1750-3841.14793.

38. Purwoko, P.; Santoso, S.B.; Permana, S.A.; Nugroho, A.; Hapsari, P.P.; Yudhistira, A. Comparison of freezedried snakehead fish albumin extract and intravenous albumin in treating patients with hypoalbuminemia. Drug Invention Today 2019, 11.

39. Prystupa, A.; Kiciński, P.; Luchowska-Kocot, D.; Sak, J.; Prystupa, T.K.; Tan, Y.-H.; Panasiuk, L.; Załuska, W. Factors influencing serum chemerin and kallistatin concentrations in patients with alcohol-induced liver cirrhosis. Ann. Agric. Environ. Med. 2019, 26, 143-147, https://doi.org/10.26444/aaem/100536.

40. Bulbul, M.R.H.; Rahman, M.A.; Rahman, M.Z.; Emran, T.B.; Afroze, M.; Khan, M.; Chowdhury, M.A.H.; Ibrahim, M.A.; Chowdhury, M.S. Leea macrophylla (Roxb.) root extract reverses CCl4 induced liver injury through upregulation of antioxidative gene expression: a molecular interaction for therapeutic inception. Advances in Traditional Medicine 2020, 20, 35-52, https://doi.org/10.1007/s13596-019-00380-2.

41. El Faras, A.A.; Elsawaf, A.L. Hepatoprotective activity of quercetin against paracetamol-induced liver toxicity in rats. Tanta Medical Journal 2017, 45, 92.

42. Kim, K.K.; Sheppard, D.; Chapman, H.A. TGF- $\beta 1$ signaling and tissue fibrosis. Cold Spring Harb. Perspect. Biol. 2018, 10, a022293, https://doi.org/10.1101/cshperspect.a022293. 
43. Fan, J.; Chen, Q.; Wei, L.; Zhou, X.; Wang, R.; Zhang, H. Asiatic acid ameliorates CCl4-induced liver fibrosis

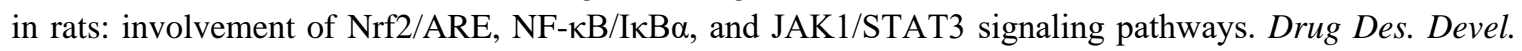
Ther. 2018, 12, 3595, https://doi.org/10.2147/DDDT.S179876.

44. Khan, Z.; Marshall, J.F. The role of integrins in TGF $\beta$ activation in the tumour stroma. Cell Tissue Res. 2016, 365, 657-673, https://doi.org/10.1007/s00441-016-2474-y.

45. Schon, H.-T.; Weiskirchen, R. Immunomodulatory effects of transforming growth factor- $\beta$ in the liver. Hepatobiliary Surgery and Nutrition; Vol 3, No 6 (December 2014): Hepatobiliary Surgery and Nutrition (Special Focus on Liver Immunology: Part I) 2014, https://doi.org/10.3978/j.issn.2304-3881.2014.11.06.

46. Robertson, I.B.; Rifkin, D.B. Regulation of the bioavailability of TGF- $\beta$ and TGF- $\beta$-related proteins. Cold Spring Harb. Perspect. Biol. 2016, 8, a021907, https://doi.org/10.1101/cshperspect.a021907.

47. Gressner, O.A.; Lahme, B.; Siluschek, M.; Rehbein, K.; Herrmann, J.; Weiskirchen, R.; Gressner, A.M. Activation of TGF- $\beta$ within cultured hepatocytes and in liver injury leads to intracrine signaling with expression of connective tissue growth factor. J. Cell. Mol. Med. 2008, 12, 2717-2730, https://doi.org/10.1111/j.1582-4934.2008.00260.x.

48. Kmiec, Z. Cooperation of liver cells in health and disease: with 18 tables; Springer Science \& Business Media: 2001; Vol. 161.

49. Fan, W.; Liu, T.; Chen, W.; Hammad, S.; Longerich, T.; Hausser, I.; Fu, Y.; Li, N.; He, Y.; Liu, C. ECM1 Prevents Activation of Transforming Growth Factor $\beta$, Hepatic Stellate Cells, and Fibrogenesis in Mice. Gastroenterology 2019, 157, 1352-1367, https://doi.org/10.1053/j.gastro.2019.07.036.

50. Maity, S.; Muhamed, J.; Sarikhani, M.; Kumar, S.; Ahamed, F.; Spurthi, K.M.; Ravi, V.; Jain, A.; Khan, D.; Arathi, B.P. Sirtuin 6 deficiency transcriptionally up-regulates TGF- $\beta$ signaling and induces fibrosis in mice. J. Biol. Chem. 2020, 295, 415-434, https://doi.org/10.1074/jbc.RA118.007212.

51. Hernández-Ortega, L.D.; Alcántar-Díaz, B.E.; Ruiz-Corro, L.A.; Sandoval-Rodriguez, A.; Bueno-Topete, M.; Armendariz-Borunda, J.; Salazar-Montes, A.M. Quercetin improves hepatic fibrosis reducing hepatic stellate cells and regulating pro-fibrogenic/anti-fibrogenic molecules balance. J. Gastroenterol. Hepatol. 2012, 27, 1865-1872.

52. Liu, Y.; Dai, E.; Yang, J. Quercetin suppresses glomerulosclerosis and TGF- $\beta$ signaling in a rat model. Mol Med Rep 2019, 19, 4589-4596, https://doi.org/10.3892/mmr.2019.10118.

53. Schett, G. Physiological effects of modulating the interleukin-6 axis. Rheumatology 2018, 57, ii43-ii50, https://doi.org/10.1093/rheumatology/kex513.

54. Hafez, M.M.; Al-Harbi, N.O.; Al-Hoshani, A.R.; Al-hosaini, K.A.; Al Shrari, S.D.; Al Rejaie, S.S.; SayedAhmed, M.M.; Al-Shabanah, O.A. Hepato-protective effect of rutin via IL-6/STAT3 pathway in CCl4induced hepatotoxicity in rats. Biol. Res. 2015, 48, 30, https://doi.org/10.1186/s40659-015-0022-y.

55. Wu, T.; Zhang, Q.; Song, H. Swertiamarin attenuates carbon tetrachloride (CCl4)-induced liver injury and inflammation in rats by regulating the TLR4 signaling pathway. Brazilian Journal of Pharmaceutical Sciences 2018, 54, https://doi.org/10.1590/s2175-97902018000417449.

56. Kawade, N.; Murai, A.; Suzuki, W.; Tokuda, Y.; Kobayashi, M.; Horio, F. Ascorbic acid deficiency increases hepatic expression of acute phase proteins through the intestine-derived IL-6 and hepatic STAT3 pathway in ODS rats. J. Nutr. Biochem. 2019, 70, 116-124, https://doi.org/10.1016/j.jnutbio.2019.04.012.

57. Xiang, D.-M.; Sun, W.; Ning, B.-F.; Zhou, T.-F.; Li, X.-F.; Zhong, W.; Cheng, Z.; Xia, M.-Y.; Wang, X.; Deng, X.; Wang, W.; Li, H.-Y.; Cui, X.-L.; Li, S.-C.; Wu, B.; Xie, W.-F.; Wang, H.-Y.; Ding, J. The HLF/IL6/STAT3 feedforward circuit drives hepatic stellate cell activation to promote liver fibrosis. Gut 2018, 67, 1704, https://doi.org/10.1136/gutjnl-2016-313392.

58. Yin, C.; Evason, K.J.; Asahina, K.; Stainier, D.Y.R. Hepatic stellate cells in liver development, regeneration, and cancer. The Journal of Clinical Investigation 2013, 123, 1902-1910, https://doi.org/10.1172/JCI66369.

59. Koyama, Y.; Brenner, D.A. Liver inflammation and fibrosis. The Journal of Clinical Investigation 2017, 127, 55-64, https://doi.org/10.1172/JCI88881.

60. Copple, B.L. Phenotypic Changes in Hepatic Stellate Cells in Response to Toxic Liver Injury. Current Pathobiology Reports 2014, 2, 155-162, https://doi.org/10.1007/s40139-014-0051-1.

61. Venturi, C.; Reding, R.; Quinones, J.A.; Sokal, E.; Rahier, J.; Bueno, J.; Sempoux, C. Relevance of activated hepatic stellate cells in predicting the development of pediatric liver allograft fibrosis. Liver Transpl. 2016, 22, 822-829, https://doi.org/10.1002/lt.24412.

62. Ramachandran, P.; Unny, A.; Vij, M.; Safwan, M.; Balaji, M.; Rela, M. \&\#945;-Smooth muscle actin expression predicts the outcome of Kasai portoenterostomy in biliary atresia. 2019, 25, 101-105, https://doi.org/10.4103/sjg.SJG_242_18. 
63. Wu, L.; Zhang, Q.; Mo, W.; Feng, J.; Li, S.; Li, J.; Liu, T.; Xu, S.; Wang, W.; Lu, X.; Yu, Q.; Chen, K.; Xia, Y.; Lu, J.; Xu, L.; Zhou, Y.; Fan, X.; Guo, C. Quercetin prevents hepatic fibrosis by inhibiting hepatic stellate cell activation and reducing autophagy via the TGF- $\beta 1 /$ Smads and PI3K/Akt pathways. Sci. Rep. 2017, 7 , 9289, https://doi.org/10.1038/s41598-017-09673-5.

64. Kisseleva, T. The origin of fibrogenic myofibroblasts in fibrotic liver. Hepatology (Baltimore, Md.) 2017, 65, 1039-1043, https://doi.org/10.1002/hep.28948.

65. Yazdani, M.; Shahdadfar, A.; Jackson, C.J.; Utheim, T.P. Hyaluronan-based hydrogel scaffolds for limbal stem cell transplantation: a review. Cells 2019, 8, 245, https://doi.org/10.3390/cells8030245.

66. Yang, Y.M.; Noureddin, M.; Liu, C.; Ohashi, K.; Kim, S.Y.; Ramnath, D.; Powell, E.E.; Sweet, M.J.; Roh, Y.S.; Hsin, I.F.; Deng, N.; Liu, Z.; Liang, J.; Mena, E.; Shouhed, D.; Schwabe, R.F.; Jiang, D.; Lu, S.C.; Noble, P.W.; Seki, E. Hyaluronan synthase 2-mediated hyaluronan production mediates Notch1 activation and liver fibrosis. Sci. Transl. Med. 2019, 11, eaat9284, https://doi.org/10.1126/scitranslmed.aat9284.

67. Orasan, O.H.; Ciulei, G.; Cozma, A.; Sava, M.; Dumitrascu, D.L. Hyaluronic acid as a biomarker of fibrosis in chronic liver diseases of different etiologies. Clujul Medical 2016, 89, 24, https://doi.org/10.15386/cjmed554.

68. Nallagangula, K.S.; Nagaraj, S.K.; Venkataswamy, L.; Chandrappa, M. Liver fibrosis: a compilation on the biomarkers status and their significance during disease progression. Future Science OA 2017, 4, FSO250, https://doi.org/10.4155/fsoa-2017-0083.

69. Hata, A.; Chen, Y.-G. TGF- $\beta$ signaling from receptors to Smads. Cold Spring Harb. Perspect. Biol. 2016, 8 , a022061, https://doi.org/10.1101/cshperspect.a022061.

70. De Luna-Saldivar, M.M.; Marino-Martinez, I.A.; Franco-Molina, M.A.; Rivera-Morales, L.G.; AlarcónGalván, G.; Cordero-Pérez, P.; Rojas-Martínez, A.; Rodríguez-Padilla, C.; Muñoz-Espinosa, L.E. Advantages of adipose tissue stem cells over CD34+ mobilization to decrease hepatic fibrosis in Wistar rats. Ann. Hepatol. 2019, 18, 620-626, https://doi.org/10.1016/j.aohep.2018.12.005.

71. Delhaye, M.; Louis, H.; Degraef, C.; Le Moine, O.; Deviere, J.; Gulbis, B.; Jacobovitz, D.; Adler, M.; Galand, P. Relationship between hepatocyte proliferative activity and liver functional reserve in human cirrhosis. Hepatology 1996, 23, 1003-1011, https://doi.org/10.1053/jhep.1996.v23.pm0008621125. 